\title{
THE INTRODUCTION OF AN ADDITIVE MODELING METHOD RESPONSIVE TO TEMPERATURE AND PRECIPITATION VARIABLES, AND ITS APPLICATIONS TO ESTIMATE THE FOREST STAND BIOMASS OF PICEA SPP. OF EURASIA
}

\author{
SHOBAIRI, S. O. R. $.^{{ }^{*}-\text { USOLTSEV, V. A. }}{ }^{2,3}-$ TSEPORDEY, I. S. ${ }^{3}$ \\ ${ }^{1}$ Research Center of Forestry Remote Sensing \& Information Engineering, Central South \\ University of Forestry and Technology, Changsha 410004, China \\ ${ }^{2}$ Faculty of Forestry, Ural State Forest Engineering University, Sibirskiy Trakt, 37, 620100 \\ Yekaterinburg, Russia \\ (e-mail: usoltsev50@mail.ru) \\ ${ }^{3}$ Botanical Garden of Ural Branch of RAS, Department of Forest Productivity, ul. 8 Marta, \\ 202a, 620144 Yekaterinburg, Russia \\ (e-mail: common@botgard.uran.ru) \\ *Corresponding author \\ e-mail: Omidshobeyri214@gmail.com \\ (Received $30^{\text {th }}$ Aug 2020; accepted $30^{\text {th }}$ Nov 2020)
}

\begin{abstract}
This article was the first attempt of modeling changes in the additive component composition of 900 spruce stands' (genus Picea sp.) biomass (t/ha), according to the trans-Eurasian hydrothermal gradients of Eurasia using the database compiled on the structure of harvest biomass. This study found that the biomass of all components increases with higher mean January temperature, regardless of mean annual precipitation, but any increase in precipitation leads to a decrease in biomass of all the components. For the first time, trans-Eurasian patterns of changes in the biomass of all components of spruce stands in the climate gradients were obtained due to the authors' first database on the biomass of forest-forming species in Eurasia. In contrast to previously published regional and transcontinental weakly adequate or unreliable regularities that are not additive in the biomass component composition and depersonalized in the species composition, in the proposed additive models for spruce, the contribution of climate variables to the explanation of biomass variability was $9 \%$. The importance of selecting the correct structure of the developed model is shown.
\end{abstract}

Keywords: climate change, additive biomass equations, January mean temperature, mean annual precipitation, regression models, biological productivity

Abbreviations: $A=$ stand age, years; $V=$ stem volume, $\mathrm{m}^{3}$ per ha; $N=$ tree density, $1000 / \mathrm{ha} ; \mathrm{Tm}=$ mean January temperature, ${ }^{\circ} \mathrm{C} ; P R m=$ mean annual precipitation, $\mathrm{mm} ; P i=$ biomass of $i$-th component, $\mathrm{t}$ per ha; involving: $P t=$ total (above- and belowground); $P a=$ aboveground; $P r=$ root; $P c=$ crown; $P s=$ stem over bark; $P w=$ stem without bark; $P b k=$ bark only; $P f=$ foliage; $P b=$ branches

\section{Introduction}

Since 1850 to the present, the amount of greenhouse gases in the atmosphere has doubled, threatening the planet with catastrophic climate change (Fatichi et al., 2019). At the UN climate summit in Paris in December 2015, 196 countries committed themselves to reducing $\mathrm{CO}_{2}$ emissions and preventing annual temperatures from rising by more than $2{ }^{\circ} \mathrm{C}$ by the end of the century. Forest ecosystems, as sinks of atmospheric carbon, play an important role in this perspective. The ability of forests to remove carbon from the atmosphere and produce organic matter is the basis of their functioning 
(Dylis, 1978). This decrease in the concentration of $\mathrm{CO}_{2}$ in the atmosphere can be achieved due to the increase of carbon stock in vegetative cover by means of effective forest management. On the other hand, climate change has a significant impact on the biological productivity of vegetation, which in turn affects the transformation of the cycle of organic matter and gas exchange in the biosphere (Golubyatnikov and Denisenko, 2009).

Temperature and precipitation are the most informative climatic factors that determine not only the radial annual growth of tree stems, but also the biological productivity of forest stands (DeLucia et al., 2000; Ni et al., 2001; Stegen et al., 2011; D'Aprile et al., 2015; Fang et al., 2016). Numerous studies of stochastic relationships of biological productivity of stands with temperature and precipitation were carried out at the regional level for indices, depersonalized by age and morphology of stands, and at the global level even without considering the species composition (Lieth, 1974; Anderson et al., 2006; Keeling and Phillips, 2007; Huston and Wolverton, 2009). Analysis of the results of such studies revealed significant contradictions and uncertainties associated with the assessment of the dependence of these indices on temperature and precipitation using both empirical and functional models (Eggers et al., 2008; Shuman, Shugart, 2009; Poudel et al., 2011; Han et al., 2018). Contradictory results were obtained even within a single region, while the influence of the same climatic factors on the biological production of stands of certain tree species (genera) in the Trans-Eurasian climatic gradients of temperature and precipitation is still unknown, since the available information is fragmentary and contradictory (Strömgren and Linder, 2002; Wilmking et al., 2004; Stegen et al., 2011; Fu et al., 2017). It was concluded that biomass-climate models developed at restricted geographic/climatic scales may not hold at broader scales and trans-continental levels (Stegen et al., 2011).

In the development of such not harmonized empirical models, the additivity of component composition is not provided, according to which the total biomass of components (stems, branches, needles, roots) obtained by component equations would be equal to the value of biomass obtained by the common equation (Dong et al., 2015). The influence of climatic changes on the biomass of a tree species in the format of additive models in accordance with transcontinental hydrothermal gradients has not been studied at all.

The purpose of this study is to develop a model of changes in the additive component composition of the Picea spp. stand biomass on the trans-Eurasian gradients of the mean January temperature and mean annual precipitation. At the same time, we intend to answer two questions: (1) to design an additive system of equations for the components of spruce stands biomass, including independent variables such as, stand dendrometric indices and hydrothermal indices inherent to ecoregions of Eurasia and compare their adequacy characteristics with the same initial equations; it is assumed that the newly constructed system of equations will be more advanced in relation to the previously calculated system based on the same harvest data (Usoltsev et al., 2019) and (2) to design 3-D dependences of biomass, additive in its components, on the climatic indices of ecoregions, combined recursively with the age, tree density and volume stock inherent to the same ecoregions. Previously, mixed models of spruce stand biomass in Eurasia were reported, including both the mentioned dendrometric variables and dummy variables as independent variables (Usoltsev et al., 2018), which encode the model's belonging to different ecoregions. It was shown that regional biomass models had significant shifts relative to ecoregions. In this study, regional shifts in the biomass 
models are quantified not by dummy variables, but by temperature and precipitation indices that are characteristic of all the ecoregions of Eurasia.

\section{Materials and experimental methods}

In the modeling process the compiled Russian database on biomass of forest-forming species of Eurasia was used (Usoltsev, 2010, 2013). The data are taken from it in the amount of 900 sample plots with the harvest biomass and dendrometric indices of the Picea spp. forest stands ( $\mathrm{t}$ per ha). The distribution of the number of sample plots by species and countries is shown in Table 1 .

Table 1. Distribution of 900 sample areas with definitions of spruce stands biomass (t/ha) by species and countries

\begin{tabular}{c|c|c}
\hline Species & Country & $\begin{array}{c}\text { Number of } \\
\text { sample plots }\end{array}$ \\
\hline Picea abies (L.) H. Karst. & $\begin{array}{c}\text { Austria, Belarus, Belgium, Bulgaria, Czech Republic, Denmark, } \\
\text { Estonia, Finland, France, Germany, Italy, Latvia, Lithuania, } \\
\text { Norway, Russia, Slovakia, Sweden, Ukraine }\end{array}$ & 486 \\
\hline P. jezoensis (S.\&Z.) Carrièr & China, Russia & 190 \\
\hline P. obovata L. & Russia & 144 \\
\hline$P$. schrenkiana F. \& C.A. Mey. & Kazakhstan, China & 58 \\
\hline$P$. sitchensis (Bong.) Carrière & Great Britain, Ireland & 12 \\
\hline P. purpurea Masters & China & 4 \\
\hline P. orientalis Link & Georgia, Russia & 4 \\
\hline P. koraiensis Nakai & Japan & 2 \\
\hline
\end{tabular}

Each sample plot on which the biomass determination was performed is positioned relatively to the isolines of the mean January temperature (Fig. I) and relatively to the isolines of mean annual precipitation (Fig. 2). The main pool of our harvest data on forest biomass in Eurasia was obtained since 1970s to 1990s, and the climate maps used cover the period of the late 1990s and early 2000s. Some discrepancy between the two time periods may cause possible biases in the results obtained, but for such a small time difference in the initial data, the inclusion of compensatory mechanisms or phenological shifts in forest communities is unlikely (Anderegg et al., 2019; DeLeo et al., 2020).

The matrix of harvest data is then compiled in a matrix, in which values of biomass component and dendrometric indices of forest stands are joint with the corresponding values of mean January temperature and precipitation. Its fragment is shown in Table 2.

The matrix was used as a source of data in the subsequent regression analysis, and recursive equations (Draper and Smith, 1973) for the different components of the stand biomass were derived:

$$
\begin{gathered}
N=\exp \left\{2.7655-0.9244(\ln A)+2.6507[\ln (T m+40)]-0.5396[\ln (T m+40)]^{2}-0.1918(\ln P R m) ;\right. \\
a d j \mathrm{R}^{2}=0.554 ; S E=0.65 \\
\downarrow \\
V=\exp \{-1.0382+1.4781(\ln A)-0.6992(\ln N)+0.2501(\ln A)(\ln N)- \\
\begin{array}{c}
\downarrow \\
2.6771[\ln (T m+40)]+0.8389[\ln (T m+40)]^{2}-0.0121(\ln P R m) ; \operatorname{adj} R^{2}=0.645 ; S E=0.85
\end{array} \\
P i=\exp \left\{\mathrm{a}_{0}+\mathrm{a}_{1}(\ln A)+\mathrm{a}_{2}(\ln V)+\mathrm{a}_{3}(\ln N)+\mathrm{a}_{4}(\ln A)(\ln N)+\mathrm{a}_{5}[\ln (T m+40)]+\mathrm{a}_{6}[\ln (T m+40)]^{2}\right. \\
\left.+\mathrm{a}_{7}(\ln P R m)\right\}
\end{gathered}
$$




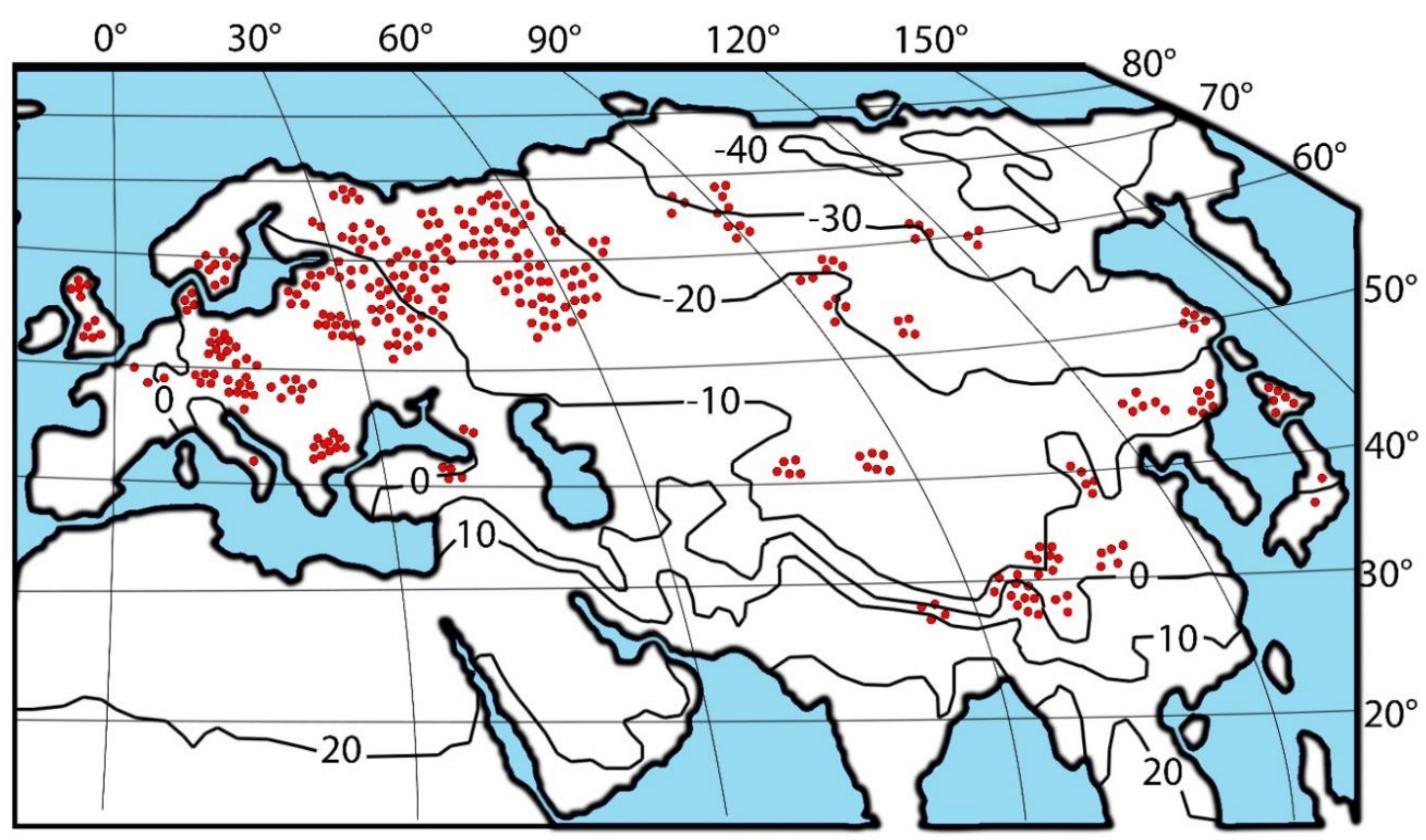

Figure 1. Distribution of 900 sample plots with harvest biomass (t per ha) of spruce stands (genus Picea sp.) on the map of the mean temperature in January, ${ }^{\circ} \mathrm{C}$ (marked by numbers)

(World Weather Maps, 2007)

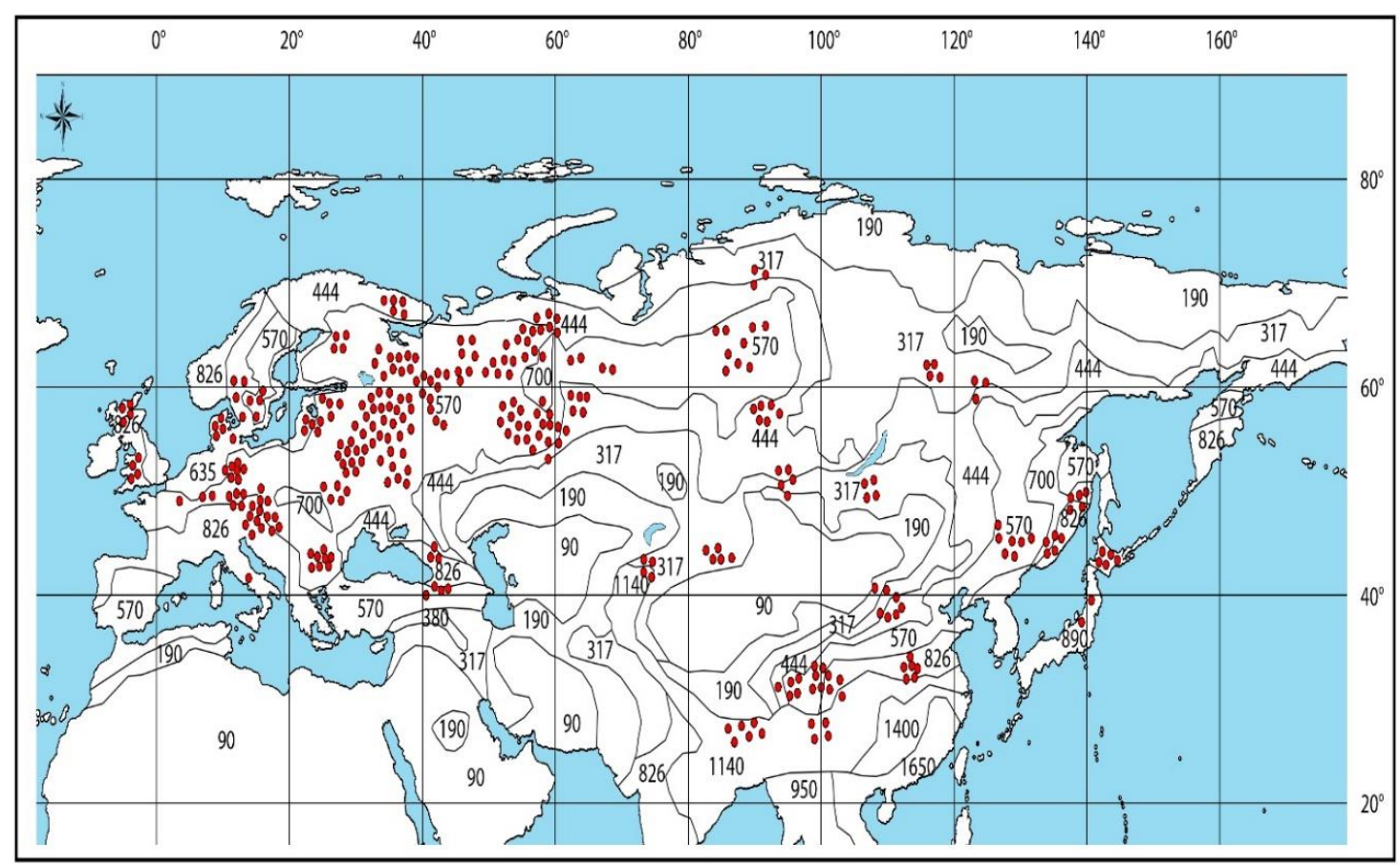

Figure 2. Distribution of 900 sample plots with harvest biomass (t per ha) of spruce stands (genus Picea sp.) on the map of mean annual precipitation, mm (marked by numbers) (World

Weather Maps, 2007, http://www.mapmost.com/world-precipitation-map/free-worldprecipitation-map/) 
Table 2. A fragment of the original matrix of 900 experimental biomass data representing Picea spp. used for the construction of additive models

\begin{tabular}{|c|c|c|c|c|c|c|c|c|c|c|c|c|c|c|c|}
\hline Country & Species & $\mathbf{N}^{\circ}$ & $\mathbf{E}^{\circ}$ & $T m$ & $P R m$ & $\boldsymbol{A}$ & $N$ & $\boldsymbol{V}$ & Ps & $P b k$ & $P b$ & $P f$ & $P a$ & $\operatorname{Pr}$ & References \\
\hline Estonia & $\begin{array}{l}\text { Picea abies } \\
\text { (L.) H.Karst. }\end{array}$ & $58^{\circ} 00^{\prime}$ & $27^{\circ} 30^{\prime}$ & -8 & 600 & 51 & 1.1 & 240 & 105.5 & 10.6 & 24.6 & 11.7 & 141.8 & 45.8 & Kõlli and Kährik, 1970 \\
\hline Estonia & P. abies & $58^{\circ} 00^{\prime}$ & $27^{\circ} 30^{\prime}$ & -8 & 600 & 84 & 0.608 & 287 & 130.1 & 10.1 & 26.6 & 13.8 & 170.5 & 64.6 & Kõlli and Kährik, 1970 \\
\hline France & P. abies & $48^{\circ} 12^{\prime}$ & $7^{\circ} 11$ & 0 & 635 & 92 & 0.568 & 614 & 234.1 & 19.1 & 19.5 & 9.2 & 262.8 & 44.5 & Persson et al., 2000 \\
\hline France & P. abies & $48^{\circ} 10^{\prime}$ & $6^{\circ} 40^{\prime}$ & 0 & 635 & 85 & 0.475 & 900 & 359.4 & 16.3 & 47.9 & 20.8 & 428.1 & 61.6 & Ranger et al., 1992 \\
\hline The Ukraine & P. abies & $48^{\circ} 45^{\prime}$ & $24^{\circ} 30^{\prime}$ & -4 & 700 & 20 & 16.523 & 127 & 43.1 & 7.5 & 10.6 & 8.4 & 62.1 & 38.6 & $\begin{array}{c}\text { Pasternak and } \\
\text { Chernyavskii, } 1977\end{array}$ \\
\hline Byelorussia & P. abies & $53^{\circ} 20^{\prime}$ & $30^{\circ} 50^{\prime}$ & -7 & 570 & 90 & 0.504 & 455 & 222.8 & 18 & 36.4 & 31.0 & 290.2 & 61.9 & Yurkevich et al., 1975 \\
\hline Belgium & P. abies & $50^{\circ} 02^{\prime}$ & $5^{\circ} 16^{\prime}$ & 2 & 730 & 55 & 1.065 & 449 & 167.9 & 11.6 & 16.6 & 16.1 & 200.6 & 70.0 & Kestemont et al., 1977 \\
\hline Bulgaria & P. abies & $43^{\circ} 00^{\prime}$ & $23^{\circ} 30^{\prime}$ & -3 & 570 & 90 & 0.385 & 773 & 296.4 & 28.9 & 58.6 & 45.4 & 400.4 & 119.3 & Grozeva et al., 1986 \\
\hline Germany & P. abies & $51^{\circ} 49^{\prime}$ & $9^{\circ} 35^{\prime}$ & -2 & 600 & 34 & 1.49 & 281 & 105.1 & 8.4 & 18.7 & 18.9 & 142.7 & 34.6 & Ellenberg et al., 1986 \\
\hline Russia & P. abies & $62^{\circ} 00^{\prime}$ & $34^{\circ} 00^{\prime}$ & -12 & 570 & 180 & 1.159 & 376 & 163.8 & 15.7 & 18.5 & 9.6 & 191.9 & 36.0 & $\begin{array}{c}\text { Shcherbakov and } \\
\text { Zaitseva, } 1971\end{array}$ \\
\hline Russia & P. abies & $62^{\circ} 00^{\prime}$ & $34^{\circ} 00^{\prime}$ & -12 & 570 & 160 & 2.733 & 310 & 134.4 & 12.3 & 16.5 & 9.6 & 160.5 & 29.6 & $\begin{array}{c}\text { Shcherbakov and } \\
\text { Zaitseva, } 1971\end{array}$ \\
\hline Russia & $\begin{array}{l}\text { P. obovata } \\
\text { (Ledeb.) } \\
\text { Loudon }\end{array}$ & $56^{\circ} 13^{\prime}$ & $92^{\circ} 19^{\prime}$ & -20 & 317 & 25 & 14.000 & 119 & 42.2 & 5.8 & 11.5 & 5.2 & 58.9 & 14.5 & Vedrova et al., 2000 \\
\hline Russia & $\begin{array}{c}P . \text { jezoensis } \\
\text { (SIEBOLD \& } \\
\text { ZUCC.) }\end{array}$ & $44^{\circ} 00^{\prime}$ & $132^{\circ} 00^{\prime}$ & -12 & 826 & 180 & 0.735 & 410 & 188.4 & 23.8 & 41.7 & 7.69 & 237.8 & 42.4 & Sapozhnikov et al., 1993 \\
\hline Russia & P. jezoensis & $44^{\circ} 00^{\prime}$ & $132^{\circ} 00^{\prime}$ & -12 & 826 & 180 & 0.753 & 364 & 195.3 & 19.5 & 30.3 & 7.6 & 233.2 & 43.9 & Sapozhnikov et al., 1993 \\
\hline China & $\begin{array}{c}\text { P. purpurea } \\
\text { Masters }\end{array}$ & $31^{\circ} 30^{\prime}$ & $103^{\circ} 32^{\prime}$ & -10 & 826 & 40 & 0.933 & 137 & 72 & 8.46 & 28.8 & 15.5 & 116.3 & 27.9 & Jiang, 1986 \\
\hline China & P. purpurea & $31^{\circ} 30^{\prime}$ & $103^{\circ} 32^{\prime}$ & -10 & 826 & 49 & 0.642 & 124 & 65 & 7.64 & 20.7 & 13.4 & 99.1 & 20.9 & Jiang, 1986 \\
\hline
\end{tabular}


We used a schematic map of the contours of the mean January temperature, rather than the mean annual temperature, as warming is most pronounced in the cold half of the year (Golubyatnikov and Denisenko, 2009; Laing and Binyamin, 2013). F. Schwarz (1899) showed at his time, the air temperature in the period from January to March to be decisive for the growth of trees is twice as strong as the precipitation in the period from May to June. Since the mean January temperature in the northern limit of Eurasia has negative values, the corresponding independent variable is modified to the form $(T m+40)$ which may be subjected to logarithmic procedure. All the necessary calculations were carried out in Statgraphics software (http://www.statgraphics.com/) with the use of a logarithm correction, by Baskerville (1972).

The first of the questions mentioned above can be answered by calculating the additive biomass equations, the structure of which is represented by Equation 3 in the recursive system shown above. According to the structure of the disaggregating model of the three-step additive system (Tang et al., 2000; Dong et al., 2015), the total biomass estimated from the initial equation is divided into component ones according to the scheme presented in Figure 3.

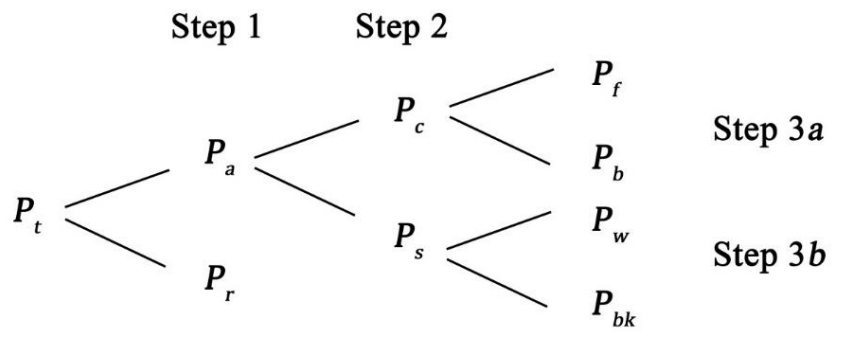

Figure 3. The pattern of disaggregating three-step proportional weighting additive model

The second question is answered by sequentially tabulating Equations 1 and 2 and combining the results with the additive system of biomass equations (Eq. 3). As a result, we obtain 3-D dependences of biomass, additive in its components, on the climatic indices in trans-Eurasian gradients, combined recursively with the age, tree density and volume stock data calculated according to Equations 1 and 2.

\section{Results and analysis}

The results of calculating Equation 3 for different biomass components are shown in Table 3. These equations are modified to additive form according to the abovementioned algorithm (Fig. 3), that was quantified earlier by Dong et al. (2015), and the final form of the transcontinental additive model of component composition of spruce biomass is shown in Table 4.

To compare the adequacy indices of the initial and additive equations, both of them are tabulated on the actual mass-forming parameters of the database, and the obtained calculated values of biomass are compared with the actual values. The comparing is fulfilled using the determination coefficient. The results of the comparison are shown in Table 5. The ratio of the actual values and the values obtained by the calculation using the initial and additive models of forest stand biomass (Fig. 4), shows the degree of correlation of these indices and the absence of visible differences in the structure of residual dispersions obtained of the two models. 

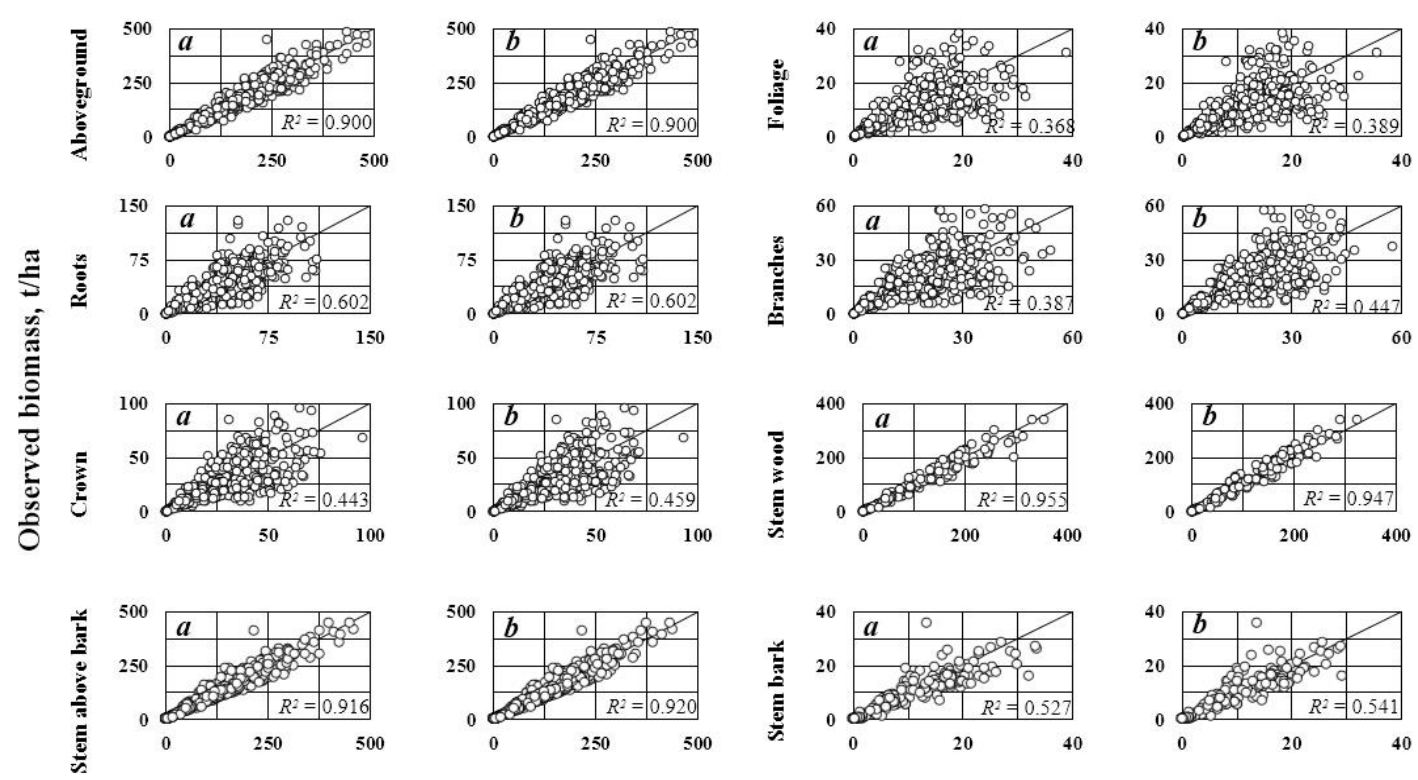

Predicted biomass, t/ha

Figure 4. The ratio of the actual values and the values obtained by calculating the initial (a) and additive (b) models of the biomass of spruce stands

The results of tabulating the equations in the sequence (1), (2) and (3) represent a rather cumbersome table. We took from it the values of component composition of spruce biomass for the age of 100 years and built figures of their dependence on temperature and precipitation (Fig. 5).

\section{Discussion}

When comparing the disaggregating method (1) for the additivity of biomass components with the previously proposed aggregating method (2) (Parresol, 1999), Dong and co-authors (Dong et al., 2015) found slightly better adequacy indices of the former in relation to the latter. They explained this phenomenon by the fact that in the second method, aggregation occurs from the tree component equations to the subtotals and then to the total one. The component equations for the biomass of foliage and branches are characterized by the largest residual dispersion, when they are subsequently combined and transferred to the subtotal (crown biomass) and then to the total (above- and belowground biomass), the residual dispersion accumulates. According to the first method, the total equation has the smallest residual variance with respect to the subtotal and tree component levels, and as a result of dividing this total equation into the component ones, accumulations of residual variance does not occur. Although the component equations for foliage and branches calculated using both the first and second methods are characterized by lower determination indices in relation to the total equations, their "binding" to the total equation calculated using the first method, as a result of component disaggregation, serves as a factor limiting the residual variance.

We can see in the data in Table 5 that of the eight component and subtotal equations, in five cases the determination indices for the first method are greater than for the second one, in two cases they are equal, and only in one case the determination index 
for the first method is less than for the second one. Apparently, in this case, the factor limiting the residual variance appears in the case of the disaggregating method, but this does not happen when calculating the initial (non-additive) equations.

After the publication of the results of calculating additive equations for spruce biomass (Usoltsev et al., 2019), a detailed meaningful analysis of the harvest data was performed. The independent variable as synergy $[\ln (T m+40)] \cdot(\ln P R m)$ was removed from the equation structure, since it was not statistically significant at 0.05 for most biomass components, but an additional independent variable was introduced in the form of synergy $(\ln A)(\ln N)$. As a result of correcting the structure of the equations, the coefficients of determination shown in Table 3 turned out to be higher in relation to those in the previously published version (Usoltsev et al., 2019), namely: for the mass of roots, crown, stem over bark, foliage, branches, stem without bark and bark were 0.7 , $0.9,0.1,0.7,1.1,0.1$ and $0.7 \%$, respectively.

Table 3. The characteristics of the initial regression equations (Eq. 3)

\begin{tabular}{|c|c|c|c|c|c|c|}
\hline \multirow{2}{*}{$\begin{array}{c}\text { Biomass } \\
\text { components }\end{array}$} & \multicolumn{6}{|c|}{ Regression coefficients of the model } \\
\hline & 2.5949 & $A^{-0.0566}$ & $V^{0.8706}$ & $N^{-0.0634}$ & \multicolumn{2}{|c|}{$A^{0.0236(\ln N)}$} \\
\hline \multicolumn{7}{|c|}{ Step 1} \\
\hline$P_{a}$ & 1.0712 & $A^{-0.0501}$ & $V^{0.8642}$ & $N^{-0.0533}$ & \multicolumn{2}{|c|}{$A^{0.0222(\ln N)}$} \\
\hline$P_{r}$ & 3.2417 & $A^{-0.0022}$ & $V^{0.8411}$ & $N^{-0.0757}$ & \multicolumn{2}{|c|}{$A^{0.0309(\ln N)}$} \\
\hline \multicolumn{7}{|c|}{ Step 2} \\
\hline$P_{c}$ & 0.6593 & $A^{-0.2440}$ & $V^{0.7177}$ & $N^{-0.1673}$ & \multicolumn{2}{|c|}{$A^{0.0899(\ln N)}$} \\
\hline$P_{s}$ & 0.3552 & $A^{0.0399}$ & $V^{0.9688}$ & $N^{-0.1400}$ & \multicolumn{2}{|c|}{$A^{0.0403(\ln N)}$} \\
\hline \multicolumn{7}{|c|}{ Step 3a } \\
\hline$P_{f}$ & -1.1338 & $A^{-0.2717}$ & $V^{0.6321}$ & $N^{-0.1895}$ & \multicolumn{2}{|c|}{$A^{0.1105(\ln N)}$} \\
\hline$P_{b}$ & 0.1374 & $A^{-0.1848}$ & $V^{0.8140}$ & $N^{-0.1546}$ & \multicolumn{2}{|c|}{$A^{0.0853(\ln N)}$} \\
\hline \multicolumn{7}{|c|}{ Step 3b } \\
\hline$P_{w}$ & -1.9166 & $A^{0.0857}$ & $V^{0.9811}$ & $N^{0.0097}$ & \multicolumn{2}{|c|}{$A^{-0.0070(\ln N)}$} \\
\hline$P_{b k}$ & -2.7983 & $A^{0.1292}$ & $V^{0.8037}$ & $N^{0.0495}$ & \multicolumn{2}{|c|}{$A^{0.0092(\ln N)}$} \\
\hline $\begin{array}{c}\text { Biomass } \\
\text { components }\end{array}$ & \multicolumn{4}{|c|}{ Regression coefficients of the model } & $\operatorname{adj} R^{2}$ & $S E$ \\
\hline$P_{t}$ & $(T m+40)^{-0.2054}$ & $(T m+40)^{0}$ & $+40)$ & $P R m^{-0.2585}$ & 0.974 & 0.23 \\
\hline \multicolumn{7}{|c|}{ Step 1} \\
\hline$P_{a}$ & $(T m+40)^{-0.0887}$ & $(T m+40)^{0}$ & $+40)$ & $P R m^{-0.1223}$ & 0.974 & 0.20 \\
\hline$P_{r}$ & $(T m+40)^{-0.7179}$ & $(T m+40)^{0}$ & $+40)$ & $P R m^{-0.4122}$ & 0.920 & 0.40 \\
\hline \multicolumn{7}{|c|}{ Step 2} \\
\hline$P_{c}$ & $(T m+40)^{0.6943}$ & $(T m+40)^{-0}$ & & $P R m^{-0.2084}$ & 0.823 & 0.41 \\
\hline$P_{s}$ & $(T m+40)^{-0.3422}$ & $(T m+40)^{0}$ & +40) & $P R m^{-0.1281}$ & 0.987 & 0.16 \\
\hline \multicolumn{7}{|c|}{ Step 3a } \\
\hline$P_{f}$ & $(T m+40)^{-0.3297}$ & $(T m+40)^{-0}$ & it+40) & $P R m^{0.0751}$ & 0.707 & 0.49 \\
\hline$P_{b}$ & $(T m+40)^{0.5843}$ & $(T m+40)^{-0}$ & c+40) & $P R m^{-0.2797}$ & 0.828 & 0.47 \\
\hline \multicolumn{7}{|c|}{ Step $3 b$} \\
\hline$P_{w}$ & $(T m+40)^{0.2977}$ & $(T m+40)^{-0}$ & i+40) & $P R m^{0.0244}$ & 0.990 & 0.15 \\
\hline$P_{b k}$ & $(T m+40)^{-0.1173}$ & $(T m+40)^{-0}$ & i+40) & $P R m^{0.1051}$ & 0.941 & 0.31 \\
\hline
\end{tabular}




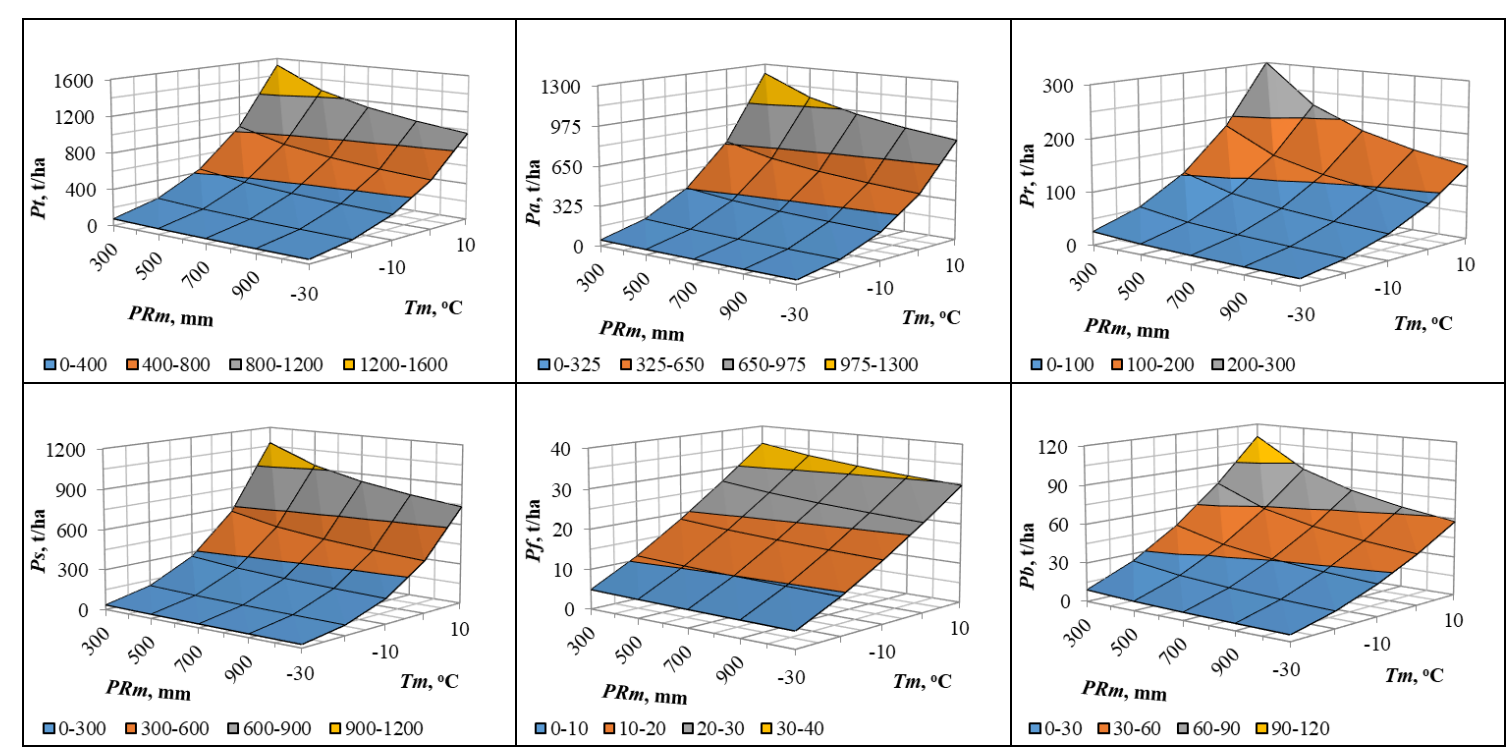

Figure 5. Dependence of spruce forest biomass upon the mean January temperature (Tm) and the mean annual precipitation (PRm)

Table 4. Three-step additive model of component composition of spruce stand biomass, implemented on the principle of proportional weighing

\begin{tabular}{|c|c|}
\hline \multirow{2}{*}{ Step 1} & $P a=\frac{1}{1+7.4724 A^{0.0731} V^{-0.0408} N^{-0.0148} N^{0.0090(\ln A)}(T m+40)^{-0.9556}(T m+40)^{0.0937(\ln (T m+40))} P R m^{-0.2033}} \times P t$ \\
\hline & $\operatorname{Pr}=\frac{1}{1+0.1338 A^{-0.0731} V^{0.0408} N^{0.0148} N^{-0.0090(\ln A)}(T m+40)^{0.9556}(T m+40)^{-0.0937(\ln (T m+40))} P R m^{0.2033}} \times P t$ \\
\hline \multirow{2}{*}{ Step 2} & $P c=\frac{1}{1+1.8924 A^{0.3496} V^{0.2112} N^{0.2452} N^{-0.0949(\ln A)}(T m+40)^{-2.0323}(T m+40){ }^{0.3826(\ln (T m+40))} P R m^{0.0537}} \times P a$ \\
\hline & $P S=\frac{1}{1+0.5284 A^{-0.3496} V^{-0.2112} N^{-0.2452} N^{0.0949(\ln A)}(T m+40)^{2.0323}(T m+40)^{-0.3826(\ln (T m+40))} P R m^{-0.0537}} \times P a$ \\
\hline \multirow{2}{*}{ Step $3 a$} & $P f=\frac{1}{1+0.4428 A^{0.2413} V^{0.1495} N^{0.1485} N^{-0.0490(\ln A)}(T m+40)^{0.0954}(T m+40)^{-0.0370(\ln (T m+40))} P R m^{-0.0812}} \times P C$ \\
\hline & $P b=\frac{1}{1+2.2583 A^{-0.2413} V^{-0.1495} N^{-0.1485} N^{0.0490(\ln A)}(T m+40)^{-0.0954}(T m+40)^{0.0370(\ln (T m+40))} P R m^{0.0812}} \times P c$ \\
\hline \multirow{2}{*}{ Step $3 b$} & $P w=\frac{1}{1+11.9129 A^{-0.0364} V^{-0.1786} N^{-0.1663} N^{0.0620(\ln A)}(T m+40)^{-1.5134}(T m+40)^{0.2563(\ln (T m+40))} P R m^{-0.2055}} \times P S$ \\
\hline & $P b k=\frac{1}{1+0.0839 A^{0.0364} V^{0.1786} N^{0.1663} N^{-0.0620(\ln A)}(T m+40){ }^{1.5134}(T m+40)^{-0.2563(\ln (T m+40))} P R m^{0.2055}} \times P S$ \\
\hline
\end{tabular}

The lack of the synergy $(\ln A)(\ln N)$ in the structure of previously published equations (Usoltsev et al., 2019) led to the fact that the residual variance, not explained by dendrometric variables, passed as "noise" to the variance explained by climate variables and reduced it. As a result of the modification of the equations, the level of variance explained by climate variables increased from 7 to $9 \%$. This is, of course, a small percentage, but we can probably consider it acceptable if we take into account that ecologists today are able to explain no more than $10 \%$ of the variability of the phenomena observed in experiments (Møller and Jennions, 2002). 
Modification of the equation structure also increased the coefficients of determination when comparing the original and additive equations on the harvest data, especially for the needle and crown biomass (compare Tables 5 and 6 ).

Table 5. Comparison of adequacy indices of initial and additive equations of spruce biomass

\begin{tabular}{|c|c|c|c|c|c|c|c|c|c|}
\hline \multirow{2}{*}{$\begin{array}{c}\begin{array}{c}\text { Coefficient of } \\
\text { determination } \\
\text { adjusted }\end{array} \\
\end{array}$} & \multicolumn{9}{|c|}{ Biomass components } \\
\hline & $P t$ & $P a$ & $P r$ & Ps & $P w$ & $P b k$ & $P c$ & $P b$ & $P f$ \\
\hline \multicolumn{10}{|c|}{ Initial equations } \\
\hline $\operatorname{adj} R^{2}$ & 0.886 & 0.900 & 0.602 & 0.916 & 0.955 & 0.527 & 0.443 & 0.387 & 0.368 \\
\hline \multicolumn{10}{|c|}{ Additive equations } \\
\hline $\operatorname{adj} R^{2}$ & 0.886 & 0.900 & 0.602 & 0.920 & 0.947 & 0.541 & 0.459 & 0.447 & 0.389 \\
\hline
\end{tabular}

Table 6. Comparison of coefficients of determination of the initial and additive equations of Picea forest biomass (Usoltsev et al., 2019)

\begin{tabular}{|c|c|c|c|c|c|c|c|c|c|}
\hline \multirow{2}{*}{$\begin{array}{c}\text { Coefficient of } \\
\text { determination } \\
\text { adjusted }\end{array}$} & \multicolumn{9}{|c|}{ Biomass components } \\
\hline & $P t$ & $P a$ & $P r$ & $P s$ & $P w$ & $P b k$ & $P c$ & $P b$ & $P f$ \\
\hline \multicolumn{10}{|c|}{ Initial equations } \\
\hline $\operatorname{adj} R^{2}$ & 0.883 & 0.898 & 0.595 & 0.912 & 0.956 & 0.533 & 0.410 & 0.363 & 0.249 \\
\hline \multicolumn{10}{|c|}{ Additive equations } \\
\hline$\overline{a d j R^{2}}$ & 0.883 & 0.899 & 0.595 & 0.919 & 0.947 & 0.541 & 0.448 & 0.443 & 0.349 \\
\hline
\end{tabular}

As it can be seen in Figure 5, all the biomass components change with temperature and precipitation gradients according to one common scheme, but in different ratios. The common pattern for all the components: regardless of the level of precipitation, when January temperature rises, the biomass of all components monotonically increases, but any increase in precipitation leads to a decrease in biomass. This is consistent with an increase of the relative radial increment, impersonal in species composition in boreal forests in Canada as the mean annual temperature increases (Miao and Li, 2011). But the dynamics of the radial increase due to the increase in precipitation, regardless of the mean annual temperature, according to the pattern by Miao and Li (2011) is directly opposite to ours.

According to the principle of limiting factors by Liebig (1840), Shelford and Metcalf (1913), plant growth is limited by an environmental factor that is at a minimum relative to a certain "norm". It is known that the variability of the annual ring width and biological productivity of stands is largely determined by the cycles of solar activity and the amount of incoming solar radiation (Douglas, 1919; Kostin, 1961; Budyko, 1977). However, in conditions of excessive moisture, where the limiting factor is the lack of oxygen in the soil, the cyclical growth is largely due to the hydrological regime of the rhizosphere (Olenin, 1982). At the other extreme, namely, the lack of moisture in steppe conditions, the tree sensitivity to precipitation increases, that is expressed in growing variability in the width of the annual rings (Ricklefs, 1979).

In some habitats, elevated temperatures can lead to stress from water scarcity and, consequently, to a decrease in biomass (Wilmking et al., 2004; Stegen et al., 2011). An increase in temperature can have a positive effect on plant productivity, provided that 
the water supply does not decrease at a higher temperature (Yang, 2005; Boivenue and Running, 2006). This was confirmed by the results of studies fulfilled in slash pine plantations in the United States, where it was found that an increase in annual precipitation by $300 \mathrm{~mm}$ practically does not change the leaf area index (LAI), which is in the range of 6 to 7. However, a decrease in precipitation by $300 \mathrm{~mm}$ causes stress, which reduces the LAI to 4 (Bracho et al., 2012).

The published results of the functional models "forest productivity-climate" are quite contradictory. Chertov (2010) believes that in the process of global warming, forest productivity increases. For the Mediterranean climate zone, it has been suggested that climate change may increase forest productivity by $12-14 \%$ and carbon storage by 23 $31 \%$ over the next 50 years (Eggers et al., 2008). For the forests of Sweden, an average regional temperature increase of $4{ }^{\circ} \mathrm{C}$ over the next 100 years is expected to increase annual forest productivity by $33 \%$ (Poudel et al., 2011). At the same time, it was found that a $2{ }^{\circ} \mathrm{C}$ temperature increase over 200 years will not significantly affect forest biomass in the Eurasian boreal forests (Shuman and Shugart, 2009). The largest biomass reserves in the zone of moderate forests were found at moderately low temperatures and moderately heavy precipitation (Keith et al., 2009).

The dependence of the radial growth of European spruce, Scots pine, and European beech trees on climate and soil water balance was studied using data from 24 sample plots in Saxony (Germany) for the period from 1951 to 2006 (Röhle et al., 2010). For each tree species, the relation of growth with 30 independent variables characterizing precipitation, air temperature, and soil water balance for different months was analyzed, which explained from 50 to $57 \%$ of the total variability of growth. By combining the obtained models with climate forecast data, it was shown that environmental conditions for spruce become more unfavorable over time, which leads to a gradual decrease in growth. For pine and beech, the negative impact of climate on radial growth could not be detected until 2100 (Röhle et al., 2010).

For the entire American continent from Canada in the North to the South of Chile (from $55^{\circ} \mathrm{N}$ to $41^{\circ} \mathrm{S}$ ), positive dependences of aboveground biomass of stands depersonalized by species composition and morphological structure on average annual precipitation were established $\left(\mathrm{R}^{2}=0.37-0.39\right)$. The relationship of biomass with the average annual temperature in tropical rainforests is positive $\left(\mathrm{R}^{2}=0.13\right)$, and in forests with excessive moisture is negative, but not statistically significant $\left(\mathrm{R}^{2}=0.02\right)$. In total, climate variables explain a small, and in many cases not statistically significant $\left(\mathrm{R}^{2}=0.02-0.03\right)$ share of forest stand biomass variability (Stegen et al., 2011).

When using the data of 56,000 sample plots in Germany and 576,000 ones in the United States, depersonalized by species composition and morphological structure of stands, it was found that an increase in the average annual temperature in Germany causes an increase, and in the United States causes a decrease in their productivity. Growing precipitation in the United States causes increased productivity, and in Germany there is an optimal level of annual precipitation (about $1000 \mathrm{~mm}$ ), beyond which additional precipitation is counterproductive (Zeller et al., 2018).

Within the territory of China, from the taiga zone in the North to the subequatorial zone in the South, when the average annual temperature increases from -2 to $14^{\circ} \mathrm{C}$, the LAI in spruce and fir stands decreases from 20 to 4, and a similar decrease was found in pine stands (Luo, 1996). In the same temperature range, net primary production (NPP) in spruce and fir stands increases, more intensively in regions of increased moisture supply. As the average annual precipitation increases from 400 to $1400 \mathrm{~mm}$, the NPP of 
these stands increases in warm regions and decreases in cold ones (Luo, 1996). A similar propeller-shaped 3-D pattern was shown for the growth of pine forests in the swamp soils of Central Siberia (Glebov and Litvinenko, 1976). In contrast to PiceaAbies spp. stands, in Larix spp., Pinus tabuliformis Carr., and Pinus koraiensis Siebold $\&$ Zucc., the NPP increases as both the average annual temperature and the average annual precipitation increase (Luo, 1996; Fang et al., 2016). In contrast to the abovenamed species, the dependence of the NPP of Chinese fir (Cunninghamia lanceolata (Lamb.) Hook.) on temperatures and precipitation under the same conditions, is represented by a dome-capped 3-D surface (Luo, 1996).

In another study, based on data from 1,340 sample plots established in six forest biomes for the main forest-forming species in China (Ni et al., 2001), positive NPP dependences on average annual precipitation $\left(R^{2}=0.42-0.86\right)$, slightly less pronounced on average annual temperature $\left(\mathrm{R}^{2}=0.31-0.60\right)$, and the least pronounced on potential evapotranspiration $\left(\mathrm{R}^{2}=0.24-0.50\right)$ are revealed. In contrast, for the southern United States, in the predictive model of potential stand productivity, temperature and precipitation were less informative than actual evapotranspiration (Manogaran, 1974).

Studies have shown that growing temperature increases the availability of soil nitrogen, and together with a longer vegetation season, this leads to an increase in tree biomass (Strömgren, Kinder, 2002). However, forest ecosystem responses to habitat include not only hydrothermal conditions, it is also difficult to account for genetically regulated changes at the physiological level. Therefore, models built on a biological basis actually have a correlative basis (Schulze, 2000). Changes in the stand NPP under the influence of annual temperatures are strongly influenced by the biodiversity index (Paquette et al., 2018). Therefore, the greatest uncertainties in assessing the impact of climate on forest biomass are typical for subtropical forests formed by hundreds of tree species in different proportions (Fu et al., 2017).

Thus, published local and regional models of forest stand productivity due to climate variables show contradictory results and do not give any knowledge of the global impact of climate shifts on forest productivity. The published trans-continental models are depersonalized by species composition and morphology of stands and show either weak or unreliable relationships with climate variables. The influence of climatic changes on the biomass of tree species in the additive format by transcontinental hydrothermal gradients has not been studied.

The creation of our first trans-Eurasian database on the biomass of forest-forming tree species is the reason why here suggested results were the first to obtain additive and statistically significant models of the total component composition of the biomass of spruce stands in Eurasia, including as independent variables both dendrometric indices of stands and climate variables, namely, average annual precipitation and average January temperature. The importance of selecting the correct structure of a developed model, which determines the level of its adequacy and ability to carry a predictive function, is shown. The obtained additive models of spruce stand biomass make them possible to establish quantitative changes in biomass structure due to climatic changes in Eurasia, in particular, due the mean temperature of January and mean annual precipitation.

\section{Conclusions}

Thus, the first attempt of modeling changes in the additive component composition of 900 spruce stands (genus Picea sp.) biomass (t/ha), according to the trans-Eurasian 
hydrothermal gradients of Eurasia is suggested using the database compiled. It is found that all the biomass components change due to the increase in temperature and precipitation according to the same common scheme, but in different ratios. A common pattern for all components: regardless of the level of precipitation, when January temperature rises, the biomass of all components monotonically increases, but any increase in precipitation leads to a decrease in biomass. The development of such models for the main forest-forming species of Eurasia will make it possible to predict changes in the productivity of the forest cover of Eurasia due to climate change. Since the contribution of climate variables to the explanation of biomass variability of different components is on average only $9 \%$, the proposed regularities are preliminary, and to increase this contribution, a more advanced database, adequate databases on trans-Eurasian temperatures and precipitation, and advanced software are needed.

Acknowledgements. The paper was funded by the Key Laboratory of Forestry Remote Sensing Based Big Data \& Ecological Security for Hunan Province, Changsha 410004, China (2016TP1014), as well as according to the programs of current scientific research of the Ural Forest Engineering University and Botanical Garden of the Ural Branch of Russian Academy of Sciences.

\section{REFERENCES}

[1] Anderegg, W. R. L., Anderegg, L. D. L., Kerr, K. L., et al. (2019): Widespread drought-induced tree mortality at dry range edges indicates that climate stress exceeds species' compensating mechanisms. - Global Change Biology 25: 3793-3802.

[2] Anderson, K. J., Allen, A. P., Gillooly, J. F., et al. (2006): Temperature-dependence of biomass accumulation rates during secondary succession. - Ecology Letters 9: 673-682.

[3] Baskerville, G. L. (1972): Use of logarithmic regression in the estimation of plant biomass. - Canadian Journal of Forest Research 2: 49-53.

[4] Boivenue, C., Running, S. (2006): Impacts of climate change on natural forest productivity - evidence since the middle of the 20th century. - Global Change Biology 12: 862-882.

[5] Bracho, R., Starr, G., Gholz, H. L., et al. (2012): Controls on carbon dynamics by ecosystem structure and climate for southeastern U.S. slash pine plantations. - Ecological Monographs 82(1): 101-128.

[6] Budyko, M. I. (1977): Global Ecology. - Mysl’ Publishing, Moscow (Rus.).

[7] Chertov, O. (2010): Impact of Temperature Increase and Precipitation Alteration at Climate Change on Forest Productivity and Soil Carbon in Boreal Forest Ecosystems in Canada and Russia: Simulation Approach with the EFIMOD Model. - In: RodriguezMorales, A., Risquez, A., Echezuria, L. (eds.) Impact of Climate Change on Health and Disease in Latin America. InTech Open Access Publisher, London.

[8] D'Aprile, F., Tapper, N., Marchetti, M. (2015): Forestry under climate change. Is time a tool for sustainable forest management? - Open Journal of Forestry 5: 329-336.

[9] DeLeo, V. L., Menge, D. N. L., Hanks, E. M., et al. (2020): Effects of two centuries of global environmental variation on phenology and physiology of Arabidopsis thaliana. Global Change Biology 26: 523-538.

[10] DeLucia, E. H., Maherali, H., Carey, E. V. (2000): Climate-driven changes in biomass allocation in pines. - Global Change Biology 6(5): 587-593.

[11] Dong, L., Zhang, L., Li, F. (2015): A three-step proportional weighting system of nonlinear biomass equations. - Forest Science 61(1): 35-45. 
[12] Douglas, A. E. (1919): Climatic Cycles and Trees-Growth. A Study of the Annual Rings of Trees in Relation to Climate and Solar Activity. - Publication No. 289. Carnegie Institution of Washington, Washington.

[13] Draper, N., Smith, H. (1973): Prikladnoy regressionnyi analiz. - Statistika, Moscow. (Translated from: Draper, N., Smith, H. 1966, Applied Regression Analysis. Wiley, New York).

[14] Dylis, N. V. (1978): Fundamentals of Biogeocenology. - Moscow State University Publishing, Moscow (Rus.).

[15] Eggers, J., Lindner, M., Zudin, S., et al. (2008): Impact of changing wood demand, climate and land use on European forest resources and carbon stocks during the 21st century. - Global Change Biology 14: 2288-2303.

[16] Ellenberg, H., Mayer, R., Schauermann, J. (1986): Ökosystemforschung - Ergebnisse des Sollingprojekts: 1966-1986. - Verlag Ulmer, Stuttgart.

[17] Fang, O., Yang Wang, Y., Shao, X. (2016): The effect of climate on the net primary productivity (NPP) of Pinus koraiensis in the Changbai Mountains over the past 50 years. - Trees 30: 281-294.

[18] Fatichi, S., Pappas, C., Zscheischler, J., et al. (2019): Modelling carbon sources and sinks in terrestrial vegetation. - New Phytologist 221(2): 652-668.

[19] Fu, L., Lei, X., Hu, Z., Zeng, W., et al. (2017): Integrating regional climate change into allometric equations for estimating tree above-ground biomass of Masson pine in China. - Annals of Forest Science 74(42): 1-15.

[20] Glebov, F. Z., Litvinenko, V. I. (1976): The dynamics of tree ring width in relation to meteorological indices in different types of wetland forests. - Lesovedenie 4: 56-62. (Rus.).

[21] Golubyatnikov, L. L., Denisenko, E. A. (2009): Influence of climatic changes on the vegetation of European Russia. - News of Russian Academy of Sciences, Geographic Series 2: 57-68.

[22] Grozeva, M., Dimitrov, E. P., Dzhorgov, I. (1986): Structure and chemical composition of the biomass in spruce stand from Rila Mountain. - Gorskostopanska Nauka 23(2): 5258. (Bulg.).

[23] Han, S. H., Kim, S., Li, G., et al. (2018): Effects of warming and precipitation manipulation on fine root dynamics of Pinus densiflora Sieb. et Zucc. Seedlings. Forests 9: 14.

[24] Huston, M. A., Wolverton, S. (2009): The global distribution of net primary production: resolving the paradox. - Ecological Monographs 79(3): 343-377.

[25] Jiang, H. (1986): Biomass and productivity of natural Picea asperata forests in close mature. - Acta Phytoecologica et Geobotanica Sinica 10(2): 146-152 (Chin.).

[26] Keeling, H. C., Phillips, O. L. (2007): The global relationship between forest productivity and biomass. - Global Ecology and Biogeography 16: 618-631.

[27] Keith, H., Mackey, B. G., Lindenmayer, D. B. (2009): Re-evaluation of forest biomass carbon stocks and lessons from the world's most carbon-dense forests. - Proceedings of the National Academy of Sciences of the United States of America 106: 11635-11640.

[28] Kestemont, P., Duvigneaud, P., Paulet, E. (1977): Biomase et productivite primaire d'une pessiere a Mirwart (Plantation de Picea abies). - In: Duvigneaud, P., Kestemont, P. (eds.)_Productivite biolodique en Belgique. Duculot, Paris, pp. 161-176.

[29] Kõlli, R., Kährik, R. (1970): Phytomass and net primary production in the forests of the Fragaria-Hepatica type. - Transactions of Estonian Agricultural Academy: Soil Regimes and Processes 65: 69-91 (Rus.).

[30] Kostin, S. I. (1961): Solar activity and its influence on the growth of trees and the state of forests in the central part of the forest-steppe of the Russian plain. - Proceedings of the Main Geophysical Observatory named after A. I. Voeikov 111: 108-117. (Rus.). 
[31] Laing, J., Binyamin, J. (2013): Climate change effect on winter temperature and precipitation of Yellowknife, Northwest Territories, Canada from 1943 to 2011. American Journal of Climate Change 2: 275-283.

[32] Liebig, J. (1840): Die organische Chemie in ihrer Anwendung auf Agricultur und Physiologie. - Verlag Vieweg, Braunschweig (Deutsches Textarchiv http://www.deutschestextarchiv.de/liebig_agricultur_1840. Accessed on 26.11.2019).

[33] Lieth, H. (1974): Modeling of primary productivity of the globe. - Soviet Journal of Ecology 2: 13-23.

[34] Luo, T. X. (1996): Patterns of biological production and its mathematical models for main forest types of China. - PhD Dissertation. Committee of Synthesis Investigation of Natural Resources, Chinese Academy of Sciences, Beijing (in Chinese with English abstract).

[35] Manogaran, C. (1974): Climatic limitations of the potential for tree growth in southern forests. - Forestry Abstracts 35(11): 642.

[36] Miao, Z., Li, C. (2011): Predicting Tree Growth Dynamics of Boreal Forest in Response to Climate Change. - In: Li, C. et al. (eds.) Landscape Ecology in Forest Management and Conservation. Higher Education Press, Beijing and Springer-Verlag, Berlin, pp. 176205.

[37] Møller, A. P., Jennions, M. D. (2002): How much variance can be explained by ecologists and evolutionary biologists? - Oecologia 132: 492-500.

[38] Ni, J., Zhang, X.-S., Scurlock, J. M. O. (2001: Synthesis and analysis of biomass and net primary productivity in Chinese forests. - Annals of Forest Science 58: 351-384.

[39] Olenin, S. M. (1982): Dynamics of radial growth of stands of pine phytocenoses of the middle taiga subzone of the Pre-Urals. - PhD thesis, Sverdlovsk (Rus.).

[40] Paquette, A., Vayreda, J., Coll, L., et al. (2018): Climate change could negate positive tree diversity effects on forest productivity: a study across five climate types in Spain and Canada. - Ecosystems 21(5): 960-970.

[41] Parresol, B. R. (1999): Assessing tree and stand biomass: a review with examples and critical comparison. - Forest Science 45: 573-593.

[42] Pasternak, P. S., Chernyavskiy, N. V. (1977): Biological productivity of Fagus-AbiesPicea young forests. - Forest Management and Forest Agromelioration 49: 27-33 (Rus.).

[43] Persson, T., van Oene, H., Harrison, A. F., et al. (2000): Experimental Sites in the NIPHYS/CANIF Project. - In: Schulze, E.-D. (ed.) Carbon and Nutrient Cycling in European Forest Ecosystems. Springer-Verlag, Berlin, pp. 14-46.

[44] Poudel, B. C., Sathre, R., Gustavsson, L., et al. (2011): Effects of climate change on biomass production and substitution in north-central Sweden. - Biomass and Bioenergy 35(10): 4340-4355.

[45] Ranger, J., Cuirin, G., Bouchon, J., et al. (1992): Biomasse et minéralomasse d'une plantation d'épicéa commun (Picea abies Karst.) de forte production dans les Vosges (France). - Annales des Sciences Forestières 49: 651-668.

[46] Ricklefs, R. E. (1979): Fundamentals of Common Ecology. - "Mir" Publishing, Moscow (Translated from: Ricklefs, R. E., 1976, The Economy of Nature: A Textbook in Basic Ecology. Chiron Press, Inc., Portland, OR.

[47] Röhle, H., Gerold, D., Gemballa, R. (2010): Beziehungen zwischen Klima und Zuwachs, dargestellt am Beispiel von Fichte, Kiefer und Buche in Sachsen. - Allgemeine Forstund Jagdzeitung 181(1/2): 21-35.

[48] Sapozhnikov, A. P., Selivanova, G. A., Il'ina, T. M., et al. (1993): Soil Forming and Peculiarities of Biological Cycle of Matters in Mountain Forests at the Southern SikhoteAlin'. - Forest Management Institute, Khabarovsk. (Rus.).

[49] Schulze, E.-D. (2000): The Carbon and Nitrogen Cycle of Forest Ecosystems. - In: Schulze, E.-D. (ed.) Carbon and Nutrient Cycling in European Forest Ecosystems. Springer-Verlag, Berlin, pp. 3-13. 
[50] Schwarz, F. (1899): Physiologische Untersuchungen über Dickenwachstum und Holzqualität von Pinus sylvestris. - P. Parey, Berlin.

[51] Shcherbakov, N. M., Zaitseva, N. L. (1971): Biometrical Characteristics of Mature Spruce Stands on the South Part of Karelia. - Forest Plant Resources of the Southern Karelia. Karelia Publishing House, Petrozavodsk, pp. 22-40 (Rus.).

[52] Shelford, V. E., Metcalf, C. (1913): Animal communities in temperate America, as illustrated in the Chicago region; a study in animal ecology. - The Geographic Society of Chicago Bulletin 13(5).

[53] Shuman, J. K., Shugart, H. H. (2009): Evaluating the sensitivity of Eurasian forest biomass to climate change using a dynamic vegetation model. - Environmental Research Letters 4(4): 1-7.

[54] Stegen, J. C., Swenson, N. G., Enquist, B. J., et al. (2011): Variation in above-ground forest biomass across broad climatic gradients. - Global Ecology and Biogeography 20(5): 744-754).

[55] Strömgren, M., Linder, S. (2002); Effects of nutrition and soil warming on stemwood production of a boreal Norway spruce stand. - Global Change Biology 8: 1195-1204.

[56] Tang, S., Zhang, H., Xu, H. (2000): Study on establish and estimate method of compatible biomass model. - Scientia Silvae Sinica 36: 19-27 (in Chinese with English abstract).

[57] Usoltsev, V. A. (2013): Forest Biomass and Primary Production Database for Eurasia. CD-Version. The Second Edition, Enlarged and Re-harmonized. - Ural State Forest Engineering University, Yekaterinburg (http://elar.usfeu.ru/handle/123456789/3059).

[58] Usoltsev, V. A. (2010): Biomass and primary production of Eurasia's forests. - Ural Branch of RAS, Yekaterinburg. (http://elar.usfeu.ru/handle/123456789/2606).

[59] Usoltsev, V. A., Shobairi, S. O. R., Chasovskikh, V. P. (2018): Triple harmonization of transcontinental allometric models of Picea spp. and Abies spp. forest stand biomass. Ecology, Environment and Conservation 24(4): 1966-1972.

[60] Usoltsev, V., Piernik, A., Osmirko, A., et al. (2019): Forest stand biomass of Picea spp.: an additive model that may be related to climate and civilisational changes. - Bulletin of Geography, Socio-Economic Series 45(45): 133-147.

[61] Vedrova, E. F., Spiridonova, L. V., Stakanov, V. D. (2000): Carbon cycle in young forests of main forest-forming species in Siberia. - Lesovedeniye 3: 40-48 (Rus.).

[62] Wilmking, M., Juday, G. P., Barber, V. A., et al. (2004): Recent climate warming forces contrasting growth responses of white spruce at treeline in Alaska through temperature thresholds. - Global Change Biology 10: 1724-1736.

[63] World Weather Maps (2007): https://www.mapsofworld.com/referrals/weather/ Accessed on 2018-06-15.

[64] Yang, Y. (2005): Factors affecting forest growth and possible effects of climate change in the Taihang Mountains, northern China. - Forestry 79: 135-147.

[65] Yurkevich, I. D., Golod, D. S., Parfenov, V. I. (1975): Problems of Biogeocoenology and Biological Productivity of Spruce Forests in Byelorussia. - Ecologic and Biological Studies of Plant Communities. Nauka i Tekhnika Publishing, Minsk, pp. 14-27 (Rus.).

[66] Zeller, L., Liang, J., Pretzsch, H. (2018): Tree species richness enhances stand productivity while stand structure can have opposite effects, based on forest inventory data from Germany and the United States of America. - Ecosystems 5: 4. 